\title{
Bone Formation in Maxillary Sinus Lift Using Autogenous Bone Graft at 2 and 6 Months
}

\author{
Formación Ósea en Elevación de Seno Maxilar \\ Usando Injerto Óseo Autógeno a los 2 y 6 Meses \\ Henrique Duque Netto*; Maria das Graças Alfonso Miranda Chaves*; \\ Beatriz Aatrstrup"; Renata Guerra* \& Sergio Olate******
}

DUQUE NETTO, H.; MIRANDA CHAVES, M. G. A.; AATRSTRUP, B.; GUERRA, R. \& OLATE, S. Bone formation in maxillary sinus lift using autogenous bone graft at 2 and 6 months. Int. J. Morphol., 34(3):1069-1075, 2016.

SUMMARY: The aim of this study is to compare the bone formation in maxillary sinus lift with an autogenous bone graft in histological evaluation at 2 or 6 months. A comparative study was designed where 10 patients with missing teeth bilaterally in the posterior zone of the maxilla were selected. Patients received a particulate autogenous bone graft under the same surgical conditions, selecting a site to collect a biopsy and histological study at two months and another at six months postoperatively. Histomorphometry was performed and were used Kolmogorov-Smirnov test, student's t-test and Spearman's correlation coefficient, considering a value of $\mathrm{p}<0.05$. Differences were observed in inflammatory infiltrate and vascularization characteristics; however, the group analyzed at two months presented $38.12 \% \pm 6.64 \%$ of mineralized tissue, whereas the group studied at 6 months presented an average of $38.45 \pm 9.27 \%$. There were no statistical differences between the groups. It is concluded that the bone formation may be similar in intrasinus particulate autogenous bone grafts in evaluations at two or six months; under these conditions, early installation of implants is viable.

KEY WORDS: Maxillary sinus; Maxillary sinus lift; Autogenous graft.

\section{INTRODUCTION}

Sinus floor elevation is a technique described as successful, with different methods of implementation. Options to manage the maxillary sinus are varied, presenting a considerable evolution in recent years.

A wide variety of bone grafts have been used in the maxillary sinus with relative success (Rickert et al., 2012). Chiapasco et al. (2008) showed in 692 patients and 952 sinus floor elevations that the success in reconstruction was between $93 \%$ to $100 \%$ and the success of implants was $95 \%$. Olate et al. (2012) showed that in 91 sinus floor elevation surgeries there were no significant differences in the results obtained after the use of different fillings, with implants installed at different times.

The anatomical variability of the maxillary sinus has demanded adaptation to different constraints. Mendoza et al. (2013) reported that the progressive increase in maxillary sinus volume may be associated on some levels with tooth loss, whereas de Moraes et al. (2012) demonstrated the relation between different sinus volumes and the amount of filling needed to cover a dental implant.

The installation times for implants placed in grafted maxillary sinuses have been described according to traditional protocols of waiting for the graft to integrate. In some studies, installation times have been based on some criteria where the integration speed of the bone graft has been poorly assessed (Chiapasco et al.).

Autogenous bone is still used with good results, where its own regenerative capacity could increase the speed of bone incorporation and regeneration. The aim of this study is to determine the formation of new bone in sinus floor elevation surgeries using an autogenous graft, comparing the histological results at 2 and 6 months from the installation.

\footnotetext{
* Mestrado em Clinica Odontológica, Faculdade de Odontología, Universidade Federal de Juiz de Fora, Minas Gerais, Brazil.

** Division of Oral and Maxillofacial Surgery \& CEMyQ, Universidad de La Frontera, Temuco, Chile.

*** Center for Biomedical Research, Universidad Autónoma de Chile, Temuco, Chile.
} 


\section{MATERIAL AND METHOD}

This study was approved by the research ethics committee of the Universidade Federal de Juiz de Fora, MG, Brazil, with number 715.348/2012. The patients included in the study participated voluntarily, signing an informed consent.

Ten patients were selected for the study. Inclusion criteria were subjects that had missing teeth, with at least one tooth involving the anatomical region of the maxillary sinus, which had to be $<4 \mathrm{~mm}$ high in the remaining alveolar bone. Subjects were excluded who had an alveolar rim higher than $5 \mathrm{~mm}$, smokers, subjects with intraoperative and postoperative complications, and those with systemic diseases that influence bone metabolism and tissue recovery.

A splint mouth study was designed involving both maxillary sinuses in sinus floor elevation surgery. Later, a study group was established where a histological study was conducted at 2 months and a control group where the study was conducted at six months. The studies were performed in the same implant installation phase.

Surgical procedure:All the patients underwent pharmacological preparation that included $1 \mathrm{~g}$ amoxicillin and $4 \mathrm{mg}$ dexamethasone and $500 \mathrm{mg}$ sodium dipyrone $1 \mathrm{~h}$ before the procedure. All the procedures occurred under local anesthesia with $2 \%$ lidocaine.

The surgical sequence included a low linear incision and a lateral, horizontal releasing incision in the anterior sector. The elevator allowed access to the zone, displacing the entire flap. A bone window was designed through routine milling of a size near $1 \mathrm{~cm}^{2}$ that made it possible to access and move the sinus membrane initially from the anterior sector, then the inferior, lateral and superior sectors. Carefully, the movements enabled release of the zone where the bone graft would be placed.

The bone was obtained from the mandibular ramus by traditional access to the zone. The bone was removed with drills bits and trephines allowing removal of blocks from the sector according to the size of the defect to be filled. The extracted bone was particulated using specific instruments and kept hydrated with $0.9 \%$ physiological saline solution.

In this stage, the particulate bone was incorporated into the sinus cavity, entering with moderate pressure until covering the sector that required the implantation process.
The maxillary sinus zone and the mandibular ramus zone were sutured with 3-0 catgut. The patient was kept on analgesic and antibiotic treatment according to the requirements of each individual case and kept under control until the implantation phase.

In all the patients, a maxillary sinus was used for dental implant installation at two months, whereas the other was chosen for the implant at six months. In this process, the first bur that entered was a trephine $2 \mathrm{~mm}$ in diameter that removed the basal bone and grafted from the maxillary sinus to then continue with the milling protocol according to the manufacturer and the installation of the dental implant.

Histological study. The samples were obtained and fixed in $10 \%$ buffered formalin for 24 hours; then they were subject to decalcification in $20 \%$ sodium citrate and $50 \%$ formic acid for 62 days. Later, with routine techniques, Hematoxylin-Eosin staining was done, obtaining $6 \mu \mathrm{m}$ cuts for analysis.

The histomorphometry was performed using image analysis with the software ZenPro 2012 (Zeizz®). Quantification was carried out by selection of areas of hard tissue $(\mu \mathrm{m} 2)$ converted to percentages by groups and simple arithmetic mean.

At this stage, characteristics were quantified and analyzed such as morphology and quantification of osteoblasts, presence of osteoid area $(\mu \mathrm{m} 2)$, tissue quality, proportion of hard and soft tissue $(\mu \mathrm{m} 2)$, presence of other inflammatory components and characteristics of the areas of necrosis.

The data were ordered on a platform of the program Microsoft Excel®, 2003. The Kolmogorov-Smirnov test, student's t-test and Spearman's correlation coefficient were used, always considering a value of $\mathrm{p}<0.05$ to examine statistically significant variables; for this the software SPSS$15^{\circledast}$ was used.

\section{RESULTS}

In group 1 (analysis at 2 months; Figs. 1 and 2) the presence of mononuclear and some polymorphonuclear inflammatory infiltrates, vascularization in the zone and presence of grafted particles were observed; there was granulation tissue in areas of bone formation and lax connective tissue. In some cases fewer blood vessels and immature bone were observed. 


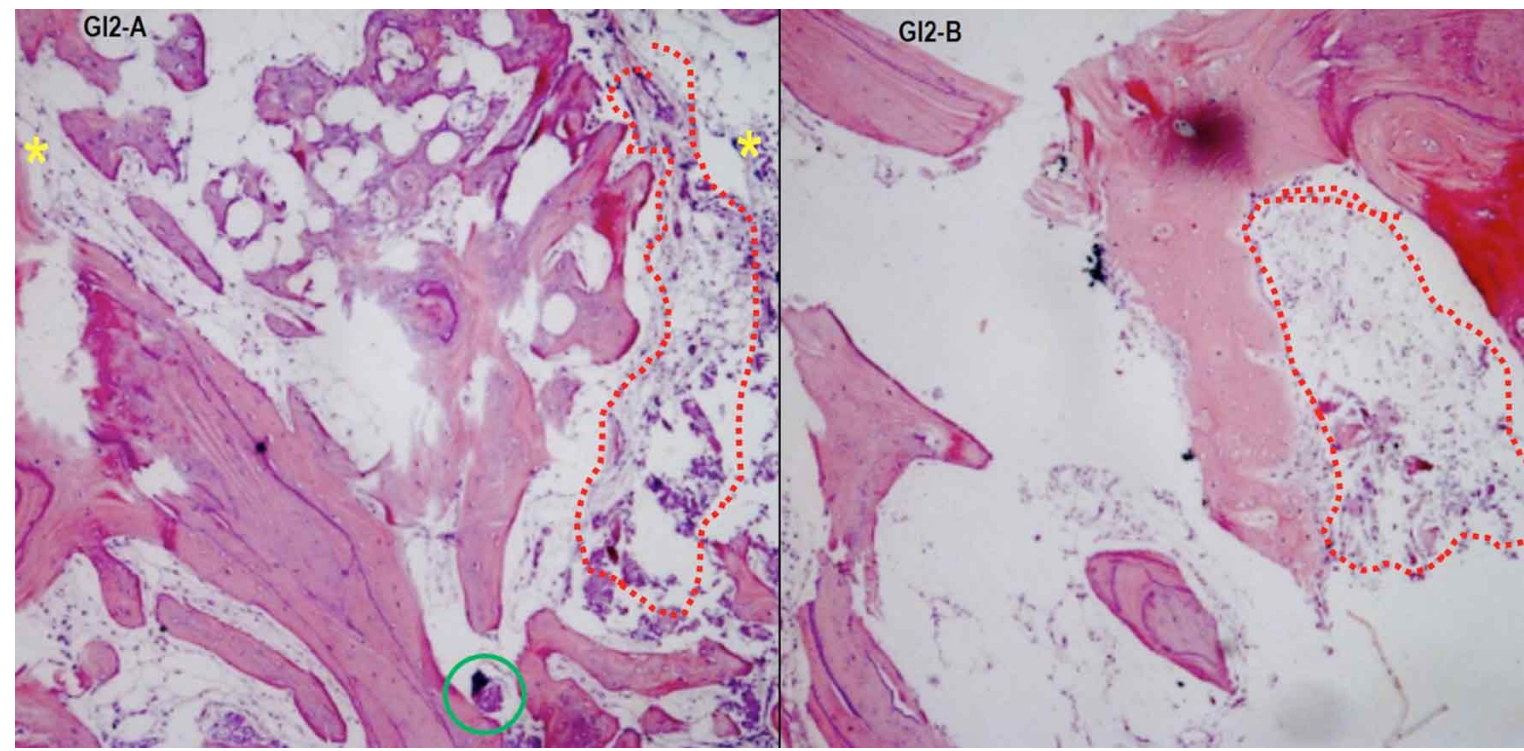

Fig. 1. Group 1 (evaluation at two months): Note the presence of mononuclear inflammatory infiltrate (yellow asterisks), vascularization and subtle particles from the graft (green circle); there is granulation tissue associated with medullary regions (red dots) and presence of new bone formation (HE, 250X).

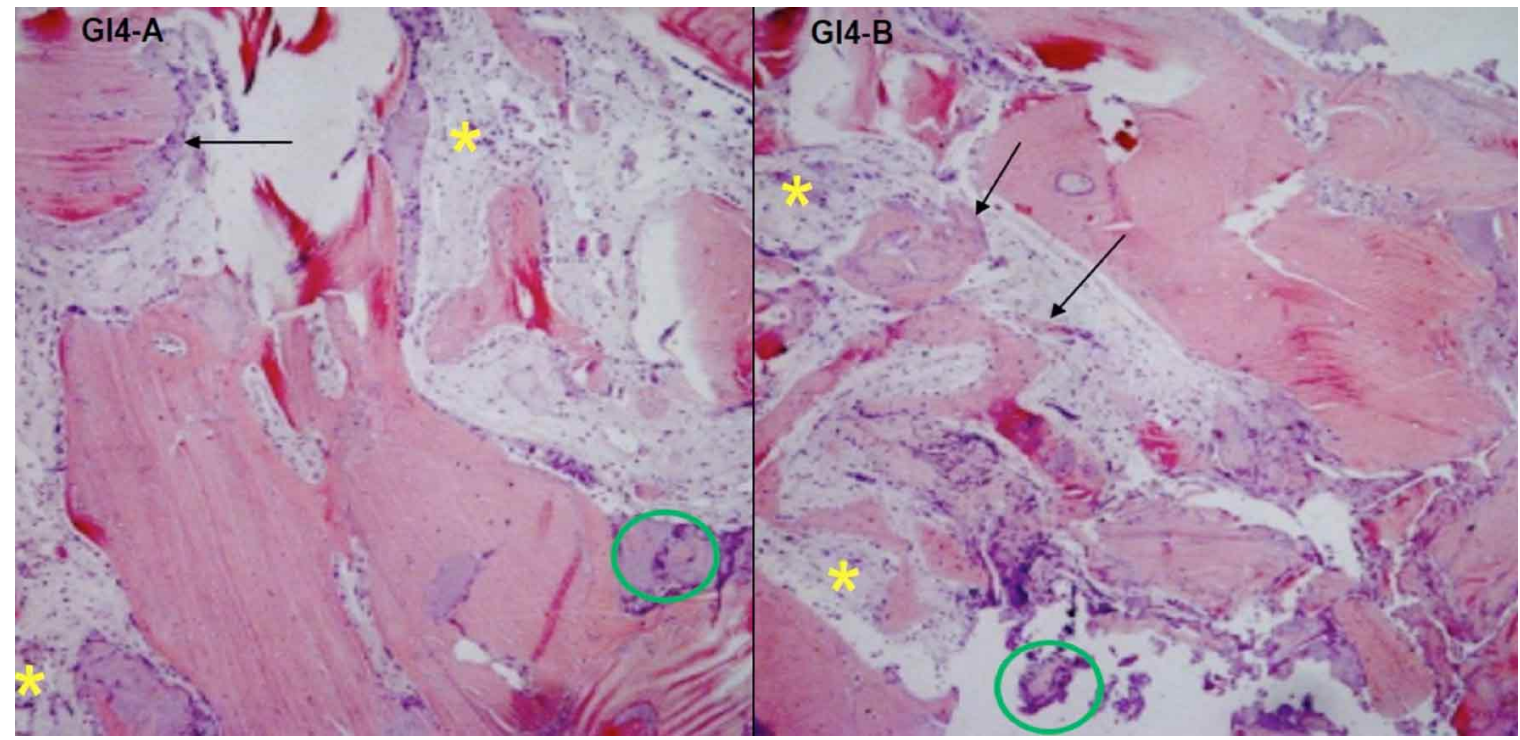

Fig. 2. Group 1 (evaluation at two months): Note a considerable polymorphonuclear and mononuclear inflammatory infiltrate (yellow asterisks), vascularization and presence of bone particles from the graft (green circle); in this image there is subtle bone formation (black arrows) (HE, 250X).

In group 2 (analyses at 6 months; Fig 3 and 4), inflammatory infiltrate with the subtle presence of mononuclear cells was observed; tissue granulation appeared in smaller amounts than at two months and newly formed bone tissue was observed on the periphery of zones of grafted bone. These observations were consistent in most of the analyses performed.

In general terms, at 6 months structured mineralized tissue was observed in all the samples, with adequate vascularization and well distributed, with the presence of granulation tissue and inflammatory infiltrate when compared to the samples in group 1.

The Kolmogorov-Smirnov test identified the normality of the data. When the two groups were compared in terms of the presence of mineralized tissue, with the student's t-test no significant differences were observed. Group 1 (analysis at 2 months) presented a mean of $38.12 \% \pm 6.64 \%$ of mineralized tissue, whereas group 2 (analysis at 6 months) had an average formation of $38.45 \pm 9.27 \%$ (Fig 5). 


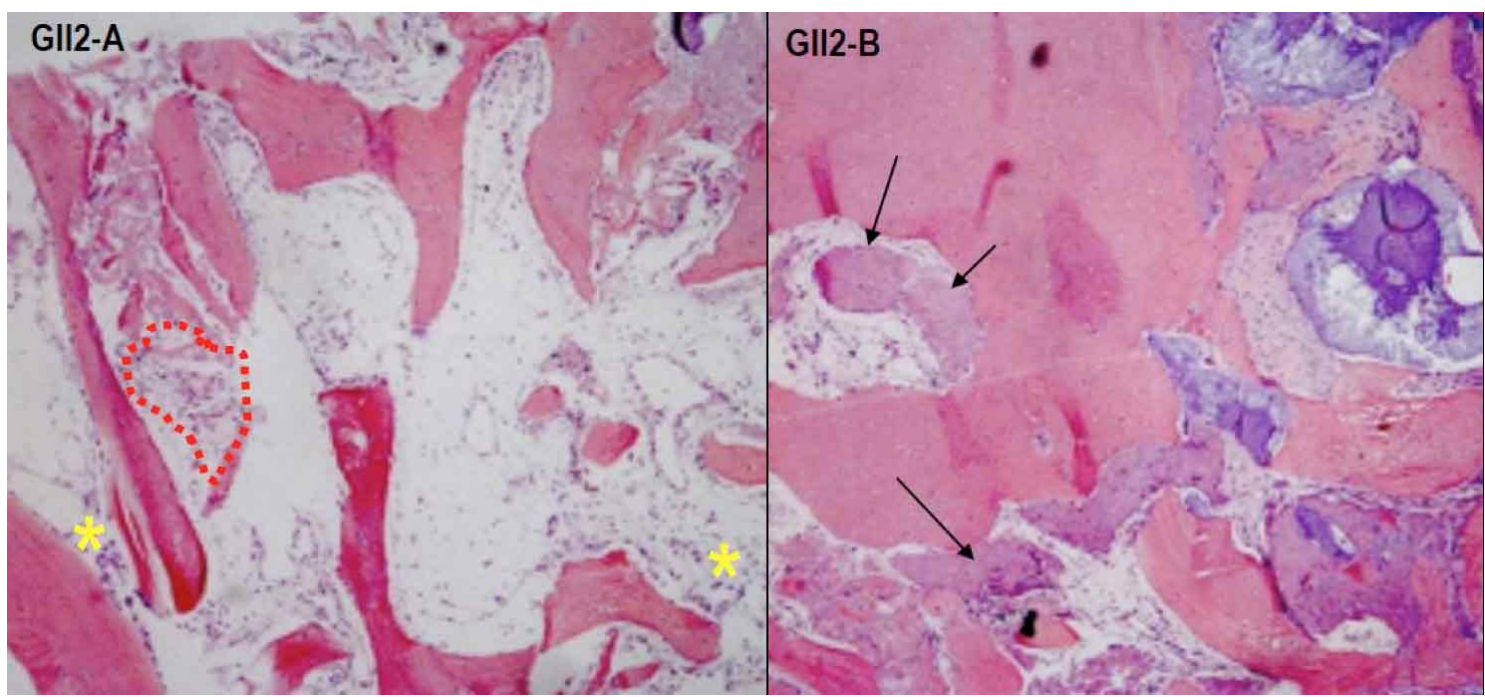

Fig. 3. Group 2 (evaluation at six months): Note the presence of subtle inflammatory infiltrate (yellow asterisks), granulation tissue (red dots) and presence of newly formed bone (black arrows) (HE, 250X).

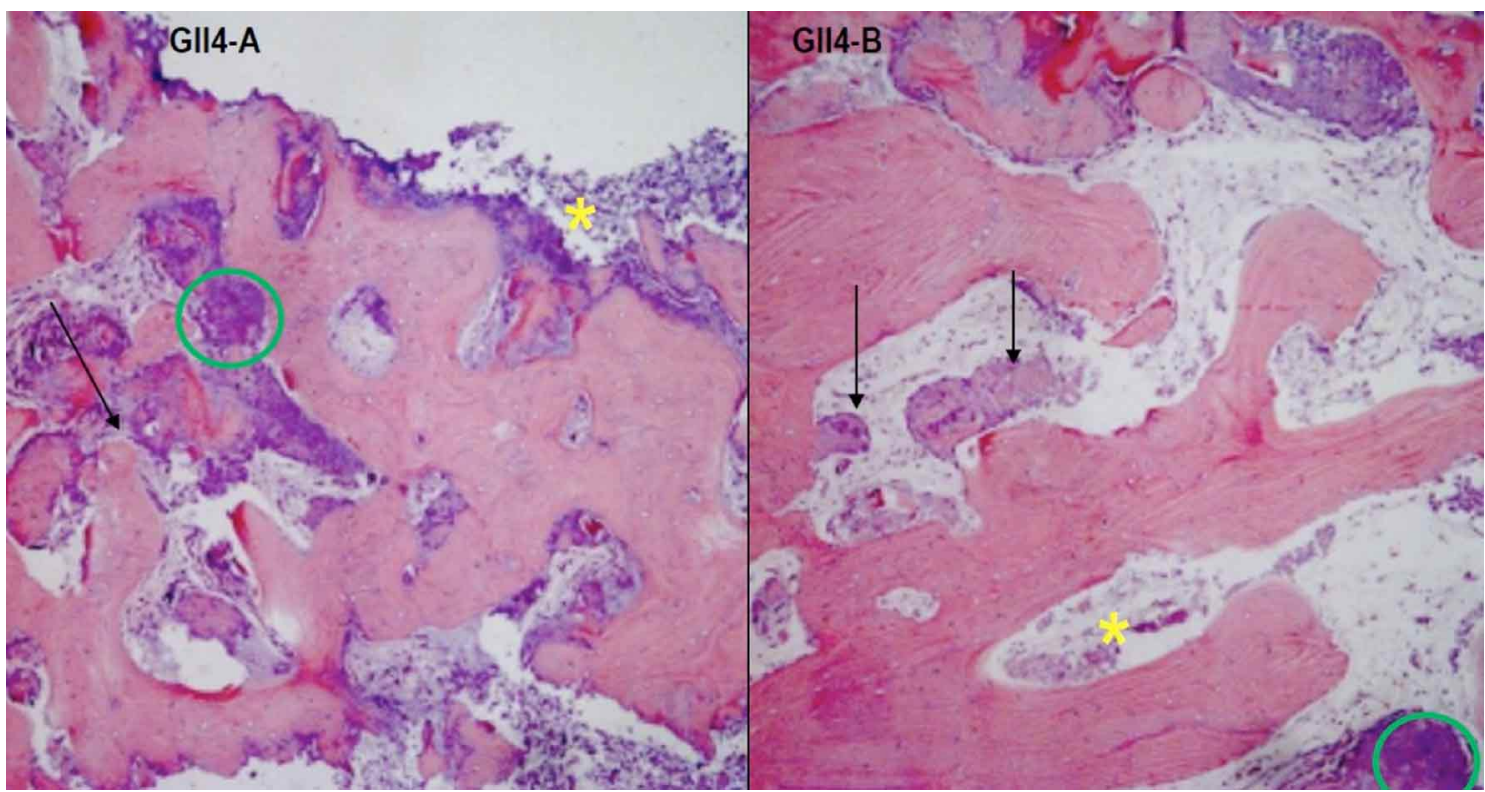

Fig. 4. Group 2 (evaluation at six months): Note a subtle mononuclear inflammatory infiltrate (yellow asterisks), vascularization and presence of particles from the graft (green circles); there is newly formed bone associated with particles from the graft (black arrows) (HE, 250X).

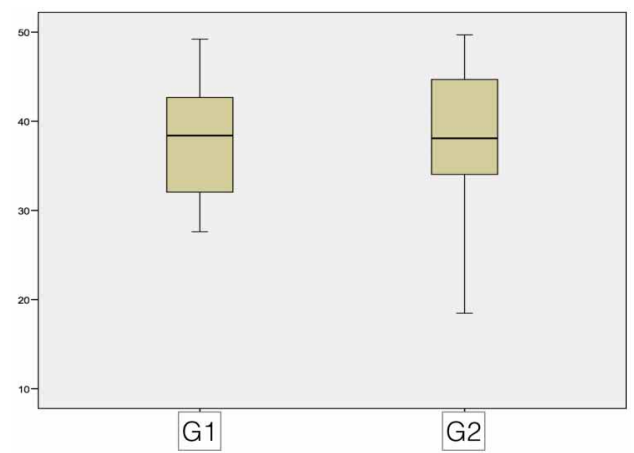

Fig. 5. Comparison of the presence of mineralized tissue in group 1 (analysis at 2 months) and group 2 (analysis at 6 months); absence of statistical correlation was determined. 


\section{DISCUSSION}

Elevation of the sinus floor has different treatment options. The crestal access and lateral window techniques, however, are the most frequently used in maxillary sinus reconstruction (Stern \& Green, 2012), where the places to obtain the transplant are varied (Sakka \& Krenkel, 2011; Arasawa et al., 2012).

Intrasinus autogenous grafts have been successful for a long time. Disadvantages observed are in the decrease in grafted volume over time and in the need for a second surgical site as a donor site (de Oliveira et al., 2013); Arasawa et al. conducted a study on 11 maxillary sinuses where each was filled with bone extracted from the iliac crest, and they observed that in 12 months there was close to a $24 \%$ loss in grafted volume; nevertheless, all the fillings were able to cover the implant totally in function. Sbordone et al. (2013) used an autogenous bone block in one group and particulate in another group, where the implants in the sites with the block were installed at 3 months and in the particulate sites at 5 months; they identified reductions in the volume of the graft in the installed block of $21.5 \%$ at 72 months, which was most pronounced in the first year; the particulate bone suffered a reduction of $39.2 \%$ in the same study period; no significant differences were observed between the groups. In the study by Johansson et al. (2010), 8 implants were inserted in sinus elevation zones with residual bone of $3 \mathrm{~mm}$ and 38 were installed in bone of 4 to $5 \mathrm{~mm}$ in height, describing a loss of height in relation to the apical zones, likely due to the bone remodeling of the area. Xavier et al. (2016) also concluded that loss of bone height was observed in biomaterials like allogenous bone and bone of bovine origin.

There is limited information regarding bone formation and early stability in autogenous bone grafts; it is possible that part of the remodeling observed over time is also generated by the times involved, from the time of installation of the graft to its use. The most important condition in this reconstruction is that the autogenous bone graft, when integrated into the receptor bed, is subject to bone remodeling, where bone resorption is a part of the remodeling (Thomas \& Puleo, 2011). Based on our results, there are no significant differences in terms of vital bone available when the installation of implants are compared at 2 or 6 months, so that this grafted site can be used for an early implant installation.

In this sense, Khairy et al. (2013) reported a study where they established a group with sinus floor elevation performed with an autogenous graft and another with autogenous bone added with platelet-rich plasma with assessment at 4 and 6 months. In the bone density analyses estimated by x-rays, no differences were observed in any of the groups where the histomorphometric findings displayed higher levels of bone formation in the autogenous bone group. It was observed that in the autogenous graft group, a numerous formation of dispersed and irregular bone with multiple osteoids and limited inflammatory infiltrate in the study periods.

The use of autogenous graft in animal experiments has shown success with a high percentage of bone-implant contact. Lee et al. (2007) installed autogenous particulate bone in canine maxillary sinus together with the implant, presenting $32 \%$ contact with implants and a $10 \%$ increase $\%$ in newly formed bone in 6 months of evaluation.

Schlegel et al. (2007) performed an investigation on an animal model, analyzing the result of autogenous bone and bovine bone with or without platelet-rich plasma, where they installed implants together with the elevation surgeries; they observed that in the first and second month of histological evaluation, the bone-implantcontact was greater in the autogenous bone, but after 12 months of evaluation the bone contact conditions showed no significant differences, where the PRP did not show any impact of improvement in bone-implant contact at any of the measurement stages. This may indicate that in early stages, the presence of autogenous bone can be useful in implant bonding. According to our results, the bone conditions at two months are highly efficient to receive function through implants installed early.

Nkenke et al. (2009) presented a systematic review where they observed that the clinical evidence neither refutes nor promotes the use of autogenous graft in sinus floor elevations, indicating that the recovery time of the graft may not be entirely related to the material used as a bone graft. Of the conclusions obtained from different biomaterials used in bone reconstruction, it is observed that there is a triad of elements that coexist in the grafted site: newly formed bone, remnants of grafted material and fibrous connective tissue, which, depending on the type of material and type of study, can be more or less the percentage of each (Proussaefs \& Lozada, 2006). In this type of analysis the assessment time of the grafted sites has been poorly evaluated, since the type of graft used and its possibility of use with implants can also be associated with the type of filling and with this the speed at which this filling integrates with its surroundings.

Under the conditions of this study, there are no significant differences in the bone repair of the elevated maxillary sinus with autogenous bone in evaluations at 2 or 6 months. 
DUQUE NETTO, H.; MIRANDA CHAVES, M. G. A.; AATRSTRUP, B.; GUERRA, R. \& OLATE, S. Formación ósea en elevación de seno maxilar usando injerto óseo autógeno a los 2 y 6 meses. Int. J. Morphol., 34(3):1069-1075, 2016.

RESUMEN: El objetivo de este estudio es comparar la formación ósea en técnicas de elevación de seno maxilar utilizando injerto óseo autógeno en evaluaciónhistológica a las 2 y 6 meses. Un estudio comparativo fue diseñado donde 10 pacientes con dientes perdidos de forma bilateral en el sector posterior de maxila fueron incluidos. Los pacientes recibieron injerto óseo particulado bajo las mismas condiciones quirúrgicas, seleccionando el sitio para tomar la biopsia y el análisis histológico respectivo a los 2 meses en un lado y 6 meses en el lado contralateral. La histomorfometría se realizó y fueron utilizadas la prueba de Kolmogorov-Smirnov, la prueba t de student y la prueba de Spearman, considerando un valor de $\mathrm{p}<0,05$. Fueron observadas diferencias en infiltrado inflamatorio y características de vascularización; sin embargo, los grupos analizados a los dos meses presentaron $38.12 \% \pm 6.64 \%$ de tejido mineralizado, mientras que los grupos de estudio a los 6 meses presentaron en promedio $38.45 \pm 9.27 \%$. No se observo diferencias significativas entre los grupos. Se concluye que la formación ósea puede ser similar en elevaciones de seno maxila realizada con hueso autógeno particulado a los dos o seis meses; en estas condiciones, la instalación temprana de implantes puede ser viable.

PALABRAS CLAVE: Seno maxilar; Elevación de seno maxilar; Hueso autógeno.

\section{REFERENCES}

Arasawa, M.; Oda, Y.; Kobayashi, T.; Uoshima, K.; Nishiyama, H.; Hoshina, H. \& Saito, C. Evaluation of bone volume changes after sinus floor augmentation with autogenous bone grafts. Int. J. Oral Maxillofac. Surg., 41(7):853-7, 2012.

Chiapasco, M.; Zaniboni, M. \& Rimondini, L. Dental implants placed in grafted maxillary sinuses: a retrospective analysis of clinical outcome according to the initial clinical situation and a proposal of defect classification. Clin. Oral Implants Res., 19(4):416-28, 2008.

de Moraes, P. H.; Costa, M. V. O. C.; Olate, S.; Caria, P. H. F. \& Barbosa, J. R. A. Morphometric study of maxillary sinus by computed tomography. Assessment of sinus floor bone reconstruction. Int. J. Morphol., 30(2):592-8, 2012.

de Oliveira, G. R.; Olate, S.; Cavalieri-Pereira, L.; Pozzer, L.; Asprino, L.; de Moraes, M. \& de Albergaría-Barbosa, J. R. Maxillary sinus floor augmentation using blood without graft material. Preliminary results in 10 patients. J. Oral Maxillofac. Surg., 71(10):1670-5, 2013.

Lee, H. J.; Choi, B. H.; Jung, J. H.; Zhu, S. J.; Lee, S. H.; Huh, J. Y.; You, T. M. \& Li, J. Maxillary sinus floor augmentation using autogenous bone grafts and platelet-enriched fibrin glue with simultaneous implant placement. Oral Surg. Oral Med. Oral Pathol. Oral Radiol. Endod., 103(3):329-33, 2007.

Johansson, L. A.; Isaksson, S.; Lindh, C.; Becktor, J. P. \& Sennerby, L. Maxillary sinus floor augmentation and simultaneous implant placement using locally harvested autogenous bone chips and bone debris: a prospective clinical study. J. Oral Maxillofac. Surg., 68(4):837-44, 2010.

Khairy, N. M.; Shendy, E. E.; Askar, N. A. \& El-Rouby, D. H. Effect of platelet rich plasma on bone regeneration in maxillary sinus augmentation (randomized clinical trial). Int. J. Oral Maxillofac. Surg., 42(2):249-55, 2013.
Mendoza, G.; Morales, P.; Reyes, F.; Navarro, P.; Garay, I. \& Olate, $\mathrm{S}$. The alveolar bone high in posterior area of maxilla and the relation with tooth loss. Int. J. Morphol., 31(3): 822-825, 2013.

Nkenke, E. \& Stelzle, F. Clinical outcomes of sinus floor augmentation for implant placement using autogenous bone or bone substitutes: a systematic review. Clin. Oral Implants Res., 20 Suppl., 4:124-33, 2009.

Olate, S.; Pozzer, L.; Luna, A. H. B.; Mazonetto, R.; de Moraes, M. \& Barbosa, J. R. A. Restrospective research in 91 maxilary sinus floor elevation surgery for implant rehabilitation. Int. J. Odontostomat., 6(1):81-8, 2012.

Proussaefs, P. \& Lozada, J. Use of titanium mesh for staged localized alveolar ridge augmentation: clinical and histologichistomorphometric evaluation. J. Oral Implantol., 32(5):23747, 2006.

Rickert, D.; Slater, J. J.; Meijer, H. J.; Vissink, A. \& Raghoebar, G. M. Maxillary sinus lift with solely autogenous bone compared to a combination of autogenous bone and growth factors or (solely) bone substitutes. A systematic review. Int. J. Oral Maxillofac. Surg., 41(2):160-7, 2012.

Sakka, S. \& Krenkel, C. Simultaneous maxillary sinus lifting and implant placement with autogenous parietal bone graft: outcome of 17 cases. J. Craniomaxillofac. Surg., 39(3):18791, 2011.

Sbordone, C.; Toti, P.; Guidetti, F.; Califano, L.; Bufo, P. \& Sbordone, L. Volume changes of autogenous bone after sinus lifting and grafting procedures: a 6-year computerized tomographic follow-up. J. Craniomaxillofac. Surg., 41(3):235-41, 2013.

Schlegel, K. A.; Zimmermann, R.; Thorwarth, M.; Neukam, F. W.; Klongnoi, B.; Nkenke, E. \& Felszeghy, E. Sinus floor 
DUQUE NETTO, H.; MIRANDA CHAVES, M. G. A.; AATRSTRUP, B.; GUERRA, R. \& OLATE, S. Bone formation in maxillary sinus lift using autogenous bone graft at 2 and 6 months. Int. J. Morphol., 34(3):1069-1075, 2016.

elevation using autogenous bone or bone substitute combined with platelet-rich plasma. Oral Surg. Oral Med. Oral Pathol. Oral Radiol. Endod., 104(3):e15-25, 2007.

Stern, A. \& Green, J. Sinus lift procedures: an overview of current techniques. Dent. Clin. North Am., 56(1):219-33, 2012.

Thomas, M. V. \& Puleo, D. A. Infection, inflammation, and bone regeneration: a paradoxical relationship. J. Dent. Res., 90(9):1052-61, 2011.

Xavier, S. P.; Santos, Tde. S.; Sehn, F. P.; Silva, E. R.; GarcezFilho, Jde. A. \& Martins-Filho, P. R. Maxillary sinus grafting with fresh frozen allograft versus bovine bone mineral: A tomographic and histological study. J. Craniomaxillofac. Surg., 44(6):708-14, 2016.
Correspondenceto:

Prof. Dr. Sergio Olate

Facultad de Odontología

Universidad de La Frontera

Claro Solar 115, Oficina 414-A

Temuco

CHILE

Email: sergio.olate@ufrontera.cl

Recibido : 12-05-2016

Aceptado: 18-07-2016 